\title{
Hydrocarbon accumulation characteristics of beach- bar sandstones in the southern slope of the Dongying Sag, Jiyang Depression, Bohai Bay Basin, China
}

\author{
Guo Song, 2*, Tan Lijuan ${ }^{3}$, Lin Chengyan ${ }^{3}$, Li Hongnan ${ }^{3}$, Lü Xiuxiang ${ }^{1,2}$ and \\ Wang Hongta ${ }^{4}$ \\ ${ }^{1}$ College of Geoscience, China University of Petroleum, Beijing 102249, China \\ ${ }^{2}$ State Key Laboratory of Petroleum Resource and Prospecting, China University of Petroleum, Beijing 102249, China \\ ${ }^{3}$ School of Geoscience, China University of Petroleum, Shandong 266580, China \\ ${ }^{4}$ Exploration and Development Research Institute, Huabei Oilfield of CNPC, Renqiu, Hebei 062552, China \\ (C) China University of Petroleum (Beijing) and Springer-Verlag Berlin Heidelberg 2014
}

\begin{abstract}
A number of beach-bar sandstone reservoir beds are developed in the upper fourth member of the Eocene Shahejie Formation $\left(\mathrm{Es}_{4}{ }^{\mathrm{s}}\right)$ on the southern slope of the Dongying Sag. Based on the analysis of seismic and logging data, with characterization and petrographic studies of core and cutting samples, this paper analyzes the hydrocarbon accumulation characteristics in two typical blocks of the Boxing and Wangjiagang oilfields, especially reservoir bed heterogeneity and migration conditions that influence oil and gas distribution, calculates the index of reservoir bed quality $\left(I_{\mathrm{RQ}}\right)$ with a mathematical method, and discusses the relationship between driving force and resistance of hydrocarbon accumulation. Taking into account the characteristics of thin interbeds in beach-bar sandstones, an experimental model simulated the characteristics of hydrocarbon migration and accumulation in thin interbedded sandstones with reservoir bed heterogeneity. The results showed that hydrocarbon distribution and properties were extremely non-uniform. Reservoir bed and migration conditions controlled hydrocarbon accumulation in beach-bar sandstones. $I_{\mathrm{RQ}}$ is above 0.4 in the main hydrocarbon region. Sand body distribution, structural configuration and fault systems controlled the direction of regional migration and location of hydrocarbon accumulation. Simulation experiments indicated that the change of driving force for hydrocarbon migration affected selective accumulation mechanisms. Hydrocarbon moved vertically along fault zones to the reservoir and resulted in the distribution of hydrocarbon in the reservoir. Two kinds of hydrocarbon accumulation models exist in the study area. One is a hydrocarbon accumulation model controlled by reservoir bed heterogeneity and the second is a hydrocarbon accumulation model controlled by a complex migration system with faults connecting sandbodies. Finally, different exploration strategies should be adopted for the detailed exploration for beach-bar sandstone reservoirs according to different geological backgrounds.
\end{abstract}

Key words: Dongying Sag, beach-bar sandstone, hydrocarbon accumulation characteristics, play elements, model experiment

\section{Introduction}

In a highly explored petroliferous basin, exhaustive study has been made on thick sand layers closely related to the main provenance. Exploration is now shifting to the area less affected by and far away from the main provenance, and the beach-bar sandstones that developed in shallow-littoral lake environments have attracted more and more attention. Oil and gas reservoirs with beach-bar sandstone payzones

*Corresponding author. email: gs-robby@163.com Received July 29, 2013 are widely distributed worldwide, including the Green River Formation (Eocene) in the Uinta Basin, USA (Borer, 2003) and the reservoirs in the Songliao, Bohai Bay, Junggar and Qaidam basins in China (Li, 2004; Wang et al, 2009; Jiang et al, 2011; Yang et al, 2011a). In recent years, researchers have studied the genetic types, sedimentary characteristics, distribution and play elements of beach-bar sandstones. In general, neritic delta, fan delta and other kinds of shallow water sand bodies are the prerequisite of the formation of beach-bars (Reid and Frostick, 1985; Zhu et al, 1994). Sandy beach-bars are developed widely on the edges and arms of lakes, or on the gentle slope of local uplifts in the lake, especially on the lakeshore with strong waves, where sandy 
components are reworked by waves and lake currents and carried to such favorable locations (Zhu et al, 1994; Zhang and Wang, 1995; Soreghan and Cohen, 1996; Otvos, 2000). Palaeogeomorphology controlled the horizontal distribution of beach-bars, and the flanks of nose structures and palaeohighs under water are the potential zones for the formation of beach-bars. In addition, the tectonic evolution period of the lake basin, palaeobathymetric condition, dynamic conditions of lake water, palaeoshoreline and distribution of other sedimentary systems also played a significant role in the development of beach-bars (Frey and Howard, 1988; Osborne and Greenwood, 1992a; 1992b; Zhu et al, 1994; Otvos, 2000; Houser and Greenwood, 2005; Guzmán and Fisher, 2006; Castelle et al, 2007; Zou, 2008; Deng et al, 2010).

Beach-bar sandstone is one of the most important types of reservoirs in the Bohai Bay Basin in east China and has become an important field for hydrocarbon exploration and exploitation in the Jiyang Depression. Although research has been about sedimentary characteristics (Li et al, 2008a; Cao et al, 2010), sedimentary models (Tian and Jiang, 2009; Yang et al, 2011b), reservoir bed characteristics (Si et al, 2008; Zou, 2008) and identification methods (Han, 2009; Li et al, 2010) of the beach-bar sandstones on the southern slope of the Dongying Sag, it is still difficult to explore for beach-bar hydrocarbon reservoirs, without adequate knowledge of hydrocarbon distribution and play elements as well as hydrocarbon accumulation mechanisms, all of which restrict the exploration for hydrocarbon reservoirs in beach-bar sandstones. Based on existing research, this paper focuses on beach-bar sandstone reservoir beds in $\mathrm{Es}_{4}{ }^{\mathrm{s}}$ on the southern slope of the Dongying Sag, and analyzes the nonuniform distribution of oil and gas and play elements in two typical blocks of the Boxing and Wangjiagang oilfields, aiming to further recognize the hydrocarbon accumulation characteristics of beach-bar sandstones on the gentle slopes of a faulted basin, which will be useful for future exploration.

\section{Material and methods}

\subsection{Geological background}

The southern slope of the Dongying Sag covers an area about $2,500 \mathrm{~km}^{2}$. It is a transition from sag to bulge with gentle slope belt characteristics and is divided into a western part and an eastern part by the Chunhua-Caoqiao Nose Structure. The western part is a large slope with developed inherited structural belts. The eastern part in a gentle horst shape is a slope as a whole rising from northwest to southeast (Fig. 1).

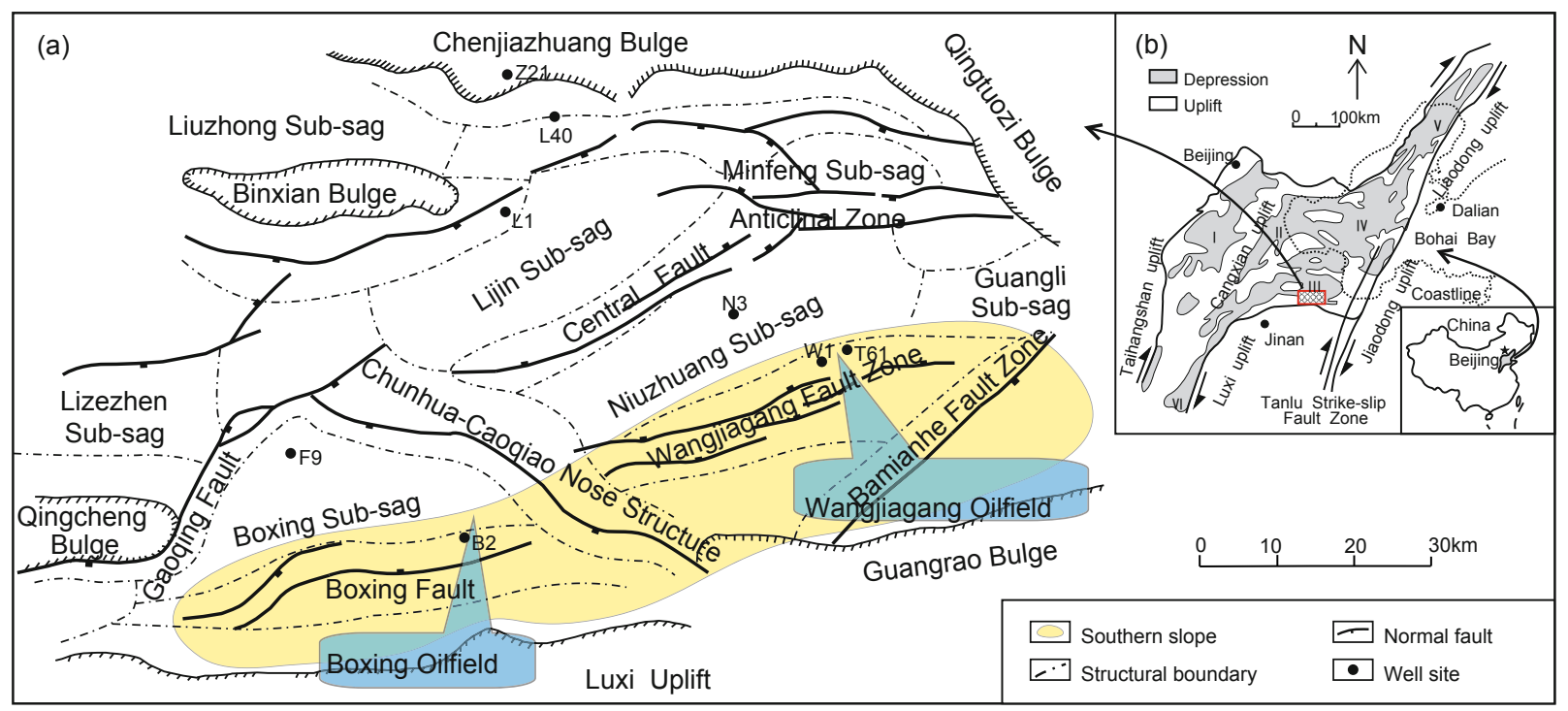

Fig. 1 Location map of the study area

(a) Map of structure of the southern slope of the Dongying Sag. The yellow area is the southern slope; (b) Tectonic setting of the Dongying Sag in the south-east corner of the Jiyang Depression 'III'. Other depressions in the Bohai Bay Basin of North China are the Huanghua Depression 'II', the Jizhong Depression 'I', the Bozhong Depression 'IV', the Liaohe Depression 'V' and the Dongpu Depression 'VI'.

The study area including the Boxing and Wangjiagang oilfields is about $200 \mathrm{~km}^{2}$. The Dongying Sag comprises Cenozoic to Quaternary basin-filling strata, locally up to 5,000 $\mathrm{m}$ thick in the depocenter, consisting of the Kongdian (Ek), Shahejie (Es), Dongying (Ed), Guantao (Ng), Minghuazhen $(\mathrm{Nm})$ and Pingyuan $(\mathrm{Qp})$ Formations. The Es Formation can be further subdivided into four members from the base to top, including $\mathrm{Es}_{4}, \mathrm{Es}_{3}, \mathrm{Es}_{2}$ and $\mathrm{Es}_{1}$ (Fig. 2). The $\mathrm{Es}_{4}$ member consists of a lower 'red bed' $\left(\mathrm{Es}_{4}{ }^{\mathrm{x}}\right.$ : red interbed of sandstone and shale) and an upper gray mudstone interbedded with fine- grained and thin-bedded sandstones $\left(\mathrm{Es}_{4}{ }^{\mathrm{s}}\right)$ which is the target stratum. $\mathrm{Es}_{4}{ }^{\mathrm{s}}$ sediments in the study area are developed in shallow-littoral lake and semi-deep lake environments from lowstand systems tract (LST) to lacustrine transgressive systems tract (TST). Impacted by palaeogeomorphology and regional tectonic setting, the beach-bar sandstones are developed better, as vertical interbeds with extensive beach sandstone. The bar sandstones with higher porosity and permeability are good locations for hydrocarbon accumulation (Zhu et al, 1994; Li et al, 2008a). 


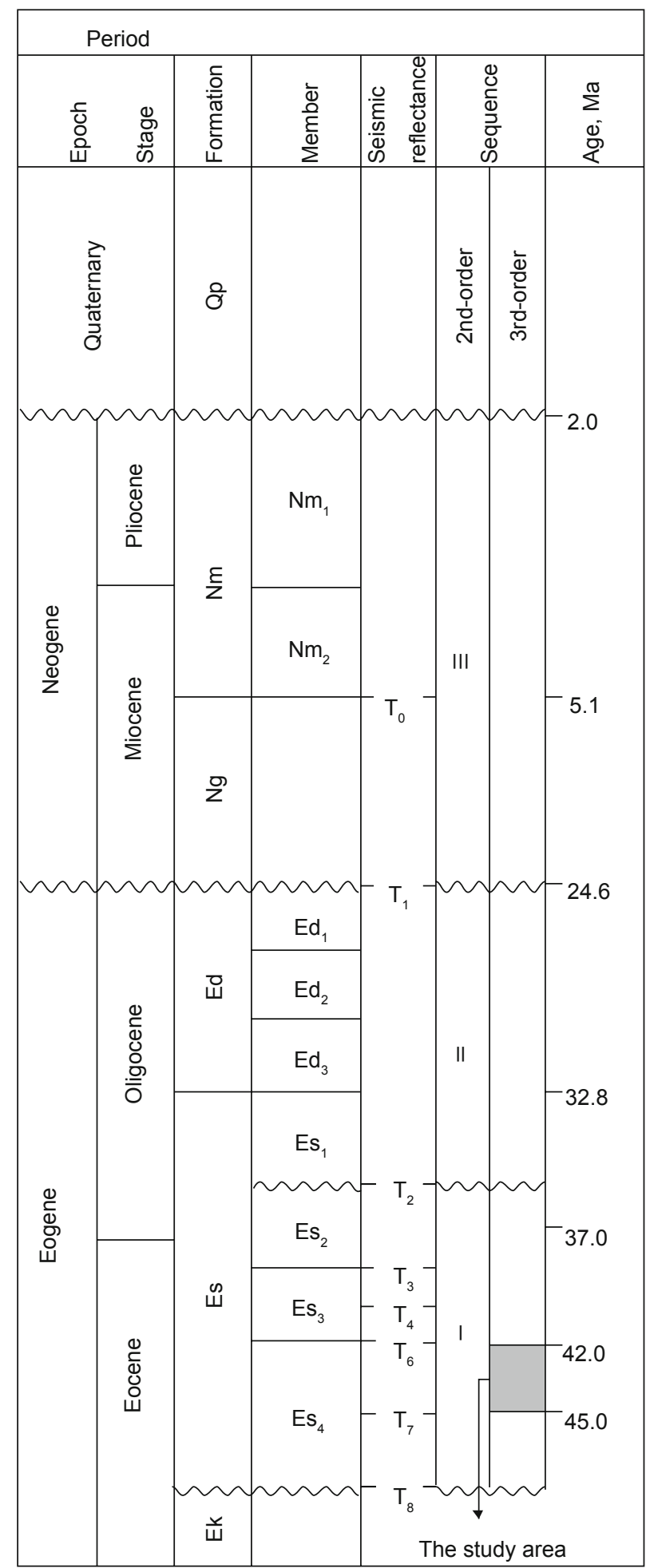

Fig. 2 Stratigraphic column and sequence framework of the study area (Jiang et al, 2011)

The Boxing oilfield is located in the western part of the southern slope and is divided into several relatively independent blocks by E-W normal faults. In this area, three major subfacies, sandy beach, sandy bar and shallow-littoral lake mudstones, are identified based on their lithologies, sedimentary structures, wireline $\log$ patterns and facies successions. A single layer of sandy beach is usually less than $2 \mathrm{~m}$ thick and is frequently interbedded with mudstone.
In plan view sandy beach deposits are distributed as mats, with poor physical properties and low productivity, and can be divided into beach mat microfacies and beach ridge microfacies. The former is the main sedimentary microfacies in this area. The sandy bar sub-facies with good physical properties and high productivity has limited distribution mainly in the shape of strips and lenses, and can be divided into main bar-body microfacies and bar-border microfacies. The shallow-littoral lake mudstone subfacies is mainly composed of gray or dark gray mudstone, shale and carbonaceous shale, but no sandstone (Wang et al, 2008).

The Wangjiagang oilfield is located in the eastern part of the southern slope. A number of faults are developed in the study area, including 16 major faults (extension of more than $3 \mathrm{~km}$, generally cutting the $\mathrm{T}_{6}$ reflection that separates the $\mathrm{Es}_{3}$ and $\mathrm{Es}_{4}$ members, the $\mathrm{T}_{7}$ reflection that separates the $\mathrm{Es}_{4}{ }^{\mathrm{s}}$ and $\mathrm{Es}_{4}{ }^{\mathrm{x}}$, the $\mathrm{T}_{8}$ reflection that separates the Es and Ek), 46 minor faults (extension less than $3 \mathrm{~km}$, fault throw 20-100 $\mathrm{m}$ ) and very many smaller faults (fault throw less than $15 \mathrm{~m}$ ), together composing a giant fault system. The study area was a shallow-littoral lake during the $\mathrm{Es}_{4}{ }^{\mathrm{s}}$ sedimentary period and three major sub-facies are identified. These are clastic rock beach-bar subfacies, carbonate rock beach-bar subfacies and braided-river deltaic front subfacies.

\subsection{Methods}

This study integrates seismic interpretation and well logging analysis, with characterization and petrographic studies of core and cutting samples to analyze hydrocarbon distribution and play elements of beach-bar sandstone in $\mathrm{Es}_{4}{ }_{4}$. The basic data include well logging data from 132 wells (70 wells in the Boxing oilfield, 62 wells in the Wangjiagang oilfield) and well testing data from 62 wells (32 wells in the Boxing oilfield, 30 wells in the Wangjiagang oilfield), which were used to make a detailed stratigraphic classification of $\mathrm{Es}_{4}{ }^{\mathrm{s}}$, draw the reservoir profiles and summarize reservoir styles and hydrocarbon distribution characteristics, and $105 \mathrm{~m}$ of core from 4 wells ( $57 \mathrm{~m}$ of core from 2 wells in the Boxing oilfield, $48 \mathrm{~m}$ from 2 wells in the Wangjiagang oilfield), 121 specimens (63 from the Boxing oilfield, 58 from the Wangjiagang oilfield) and 40 thin sections (22 thin sections in the Boxing oilfield, 18 thin sections in the Wangjiagang oilfield) were studied to help explain the diagenesis and transport pathways of beach-bars. A mathematical method is proposed to calculate the index of reservoir bed quality $\left(I_{\mathrm{RQ}}\right)$ to define the control of hydrocarbon accumulation by reservoir bed condition. The characteristics of hydrocarbon migration and accumulation in thin interbedded sandstones were simulated with an experimental model of reservoir bed heterogeneity in the Reservoir \& Geology Key Laboratory of Shandong Province, China University of Petroleum, Qingdao, and the hydrocarbon accumulation mechanism was analyzed. A different exploration policy for beach-bar reservoirs is proposed based on different geological backgrounds.

\section{Results and discussion}

\subsection{Non-uniform distribution of hydrocarbon}

Beach-bar sandstones are usually developed in high- 
energy shallow-littoral lake environments. They are typically characterized by thin interbedding, remarkable spatial changes of sandbodies and strong heterogeneity. Hydrocarbon distribution in beach-bars is usually non-uniform. Nonuniform distribution of hydrocarbon in sandbodies of different sizes and backgrounds has different forms, mechanisms and controlling factors. In the study area, hydrocarbon distribution is non-uniform on the plane, oil and gas can be found in different horizons with different oil-bearing areas. Vertically, one sandstone group is possibly different from others, one sandstone bed may have oil and gas while its overlying or underlying neighbor has no oil or gas.
The accumulation of hydrocarbon is relatively complicated in the beach-bar sandstone reservoir beds of $\mathrm{Es}_{4}{ }^{\mathrm{s}}$ in the Boxing oilfield. Oil and gas are found mainly in the T83-C95 well block with numerous faults and the B3 well block comprising main bar-body microfacies and bar-border microfacies with thick sand. In the vertical direction, the hydrocarbon accumulation features of six sand groups are also different. Sandstone group 1 is the best payzone with higher porosity and permeability, and sandstone group 3 is the next (Fig. 3).

The characteristics of hydrocarbon distribution in the Wangjiagang oilfield are similar to those in the Boxing oilfield. The reserves and oil-bearing areas of different sand
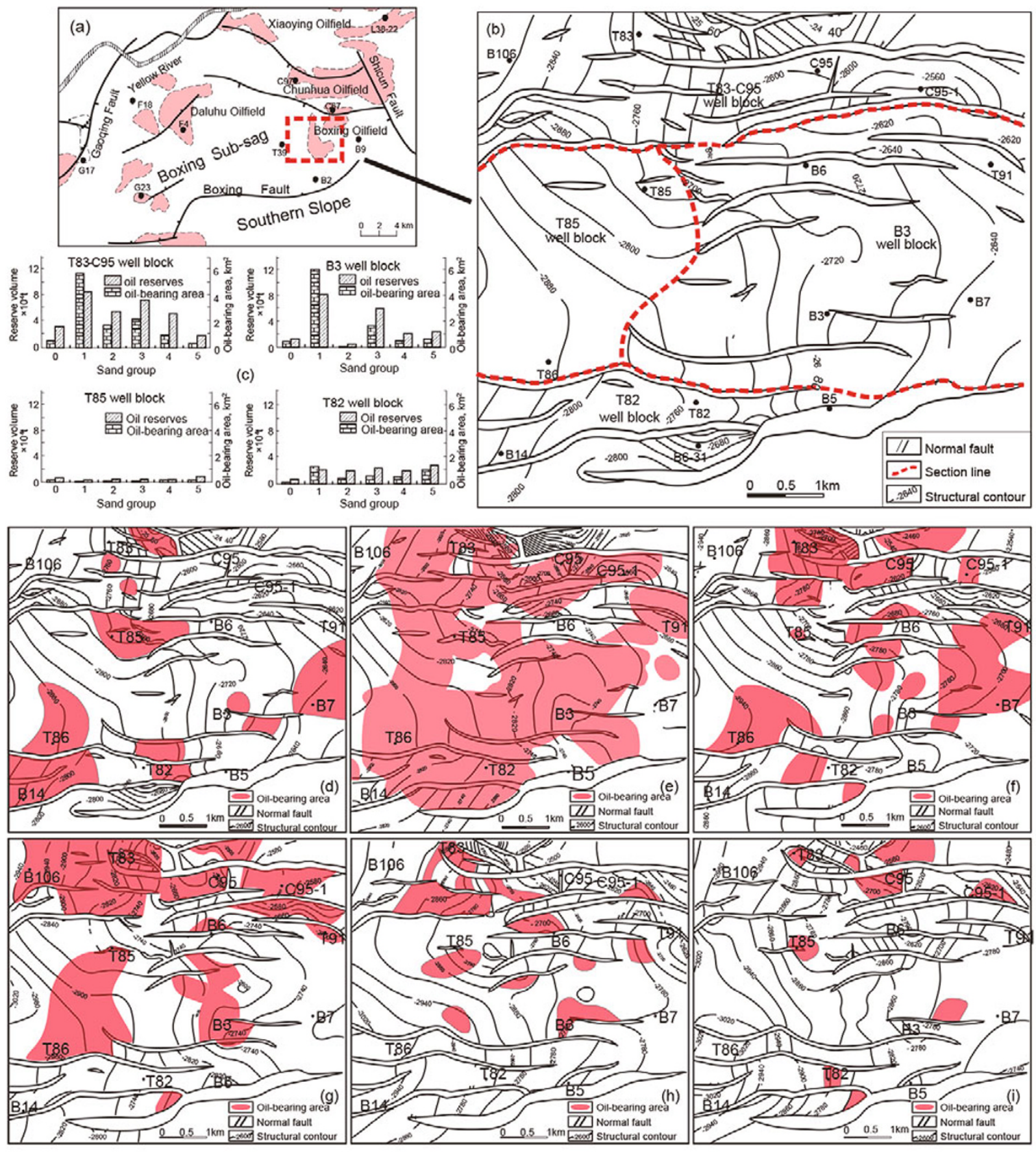

Fig. 3 Sketch map showing reserves and oil-bearing areas of $\mathrm{Es}_{4}{ }^{\mathrm{s}}$ in the Boxing oilfield.

(a) Structural map of the Boxing Sub-sag; (b) Structural map of $\mathrm{Es}_{4}{ }^{\mathrm{s}}$ in the Boxing oilfield with division of well blocks; (c) Reserves and oil-bearing areas of different well blocks and sand groups in the study area; (d-i) Oil-bearing areas of sand group 0-5 
groups are different. Sandstone group 1 is the best payzone, and sandstone group 3 is the next. On the plane, three fault blocks of L32, W24-40 and W24-32 contain most of oil and gas, accounting for $88 \%$ (Fig. 4).

Beach-bar sedimentary systems are developed in shallowlittoral lake environments with strong changes of lithology and physical properties on the plane. Lithologic, capillary sealing and structural-lithologic reservoirs are common (Tan and Guo, 2011). The reservoir types in the Boxing oilfield are mainly capillary sealing and fault-lithologic reservoirs, however, in the Wangjiagang oilfield there are fault-block and fault-nose reservoirs.
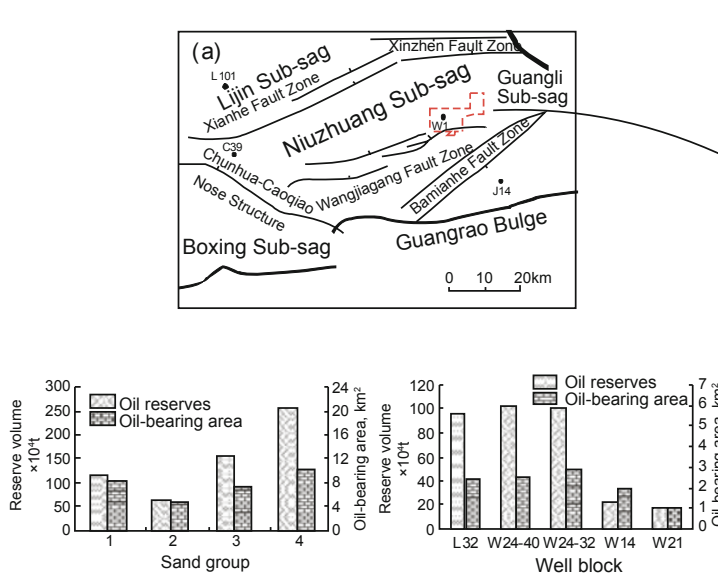

(c)

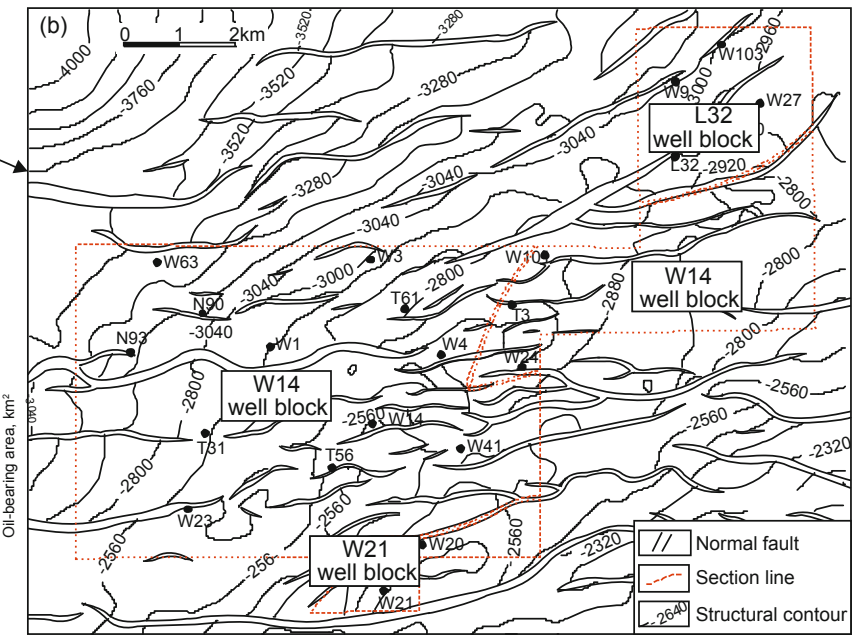

Fig. 4 Comparison of oil reserves in the Wangjiagang oilfield.

(a) Structural map of Niuzhuang Sub-sag; (b) Structural map of $\mathrm{Es}_{4}{ }^{\mathrm{s}}$ in the Wangjiagang oilfield with division of well blocks; (c) Reserves and oil-bearing areas of different well blocks and sand groups in the study area (Based on oil production data, W24 well field is sub-divided into W24-40 and W24-32 well blocks)

\subsection{Play elements}

According to previous findings, there are two sets of source rocks in $\mathrm{Es}_{3}$ and $\mathrm{Es}_{4}{ }^{\mathrm{s}}$ on the southern slope of the Dongying Sag (Zhu et al, 2004; Li et al, 2006; 2008b). Source rock research and oil-source correlation proved that the characteristics of biomarkers of crude oil in the study area accord with the source rock in $\mathrm{Es}_{4}{ }^{\mathrm{s}}$ (Yang and Zhang, 2008). The difference is that the crude oil in the Boxing oilfield is mainly from the Boxing Sub-sag, but the crude oil in the Wangjiagang oilfield is mainly from the Niuzhuang Subsag (Tan et al, 2002; Yang and Zhang, 2008). Based on the analysis of play elements in $\mathrm{Es}_{4}{ }^{\mathrm{s}}$, hydrocarbon accumulation in each sandstone group is diverse, determined by migration conditions and reservoir bed quality instead of hydrocarbon source and structural configuration, though the hydrocarbon source and the succession of structural configurations are similar in different parts and sandstone groups.

\subsubsection{Control of hydrocarbon distribution by reservoir bed condition}

1) Reservoir bed heterogeneity and non-uniform distribution of hydrocarbon

The average porosity is $12.8 \%$ and the average permeability is $5.5 \times 10^{-3} \mu^{2}$ in the beach-bar sandstone reservoir beds of $\mathrm{Es}_{4}{ }^{\mathrm{s}}$ in the Boxing oilfield. Oil and gas are present firstly in siltstone, and next in muddy and limy siltstone. The reservoir bed quality and degree of hydrocarbon accumulation are different in different lithologies, and most reservoir beds are dry beds. The average porosity is $15.9 \%$ and the average permeability is $26.5 \times 10^{-3} \mu^{2}$ in the beach-bar sandstone reservoir beds of $\mathrm{Es}_{4}{ }^{\mathrm{s}}$ in the Wangjiagang oilfield. Oil and gas are present in fine sandstone and silty sandstone. The reservoir bed quality in the Wangjiagang oilfield is better than that in the Boxing oilfield, but with more water layers (Fig. 5).

The reservoir beds in $\mathrm{Es}_{4}{ }^{\mathrm{s}}$ with low porosity and permeability are affected by diagenesis. In the Boxing oilfield, sandstone is mainly composed of firstly lithic arkose, then feldspathic litharenite and arkose. According to the analysis of thin sections and diagenesis, the reservoir bed pore space is dominated by secondary pores, and precipitation and dissolution of calcite and feldspar denudation are responsible for the change of porosity. The diagenetic characteristics show that this set of sandstone is at the early stage of intermediate diagenetic period ( $\mathrm{Si}$ et al, 2008). In the Wangjiagang oilfield, sandstone is mainly composed of lithic arkose, feldspathic fine sandstone or coarse silt, and muddy feldspathic fine siltstone. After alternating acid-alkaline diagenetic evolution, reservoir beds are at the late stage of the early diagenetic period to the early stage of the intermediate diagenetic period. Diagenetic alteration, compaction and cementation would destroy porosity, but dissolution of calcite and feldspar forms secondary pores and improves reservoir bed quality. Influenced by diagenesis, beach-bar sandstones show strong heterogeneity, leading to different reservoir bed qualities in different areas (Song, 2005).

In the process of hydrocarbon accumulation in reservoirs, sandstone provides the hydrocarbon migration pathways and also offers necessary space for hydrocarbon accumulation. 

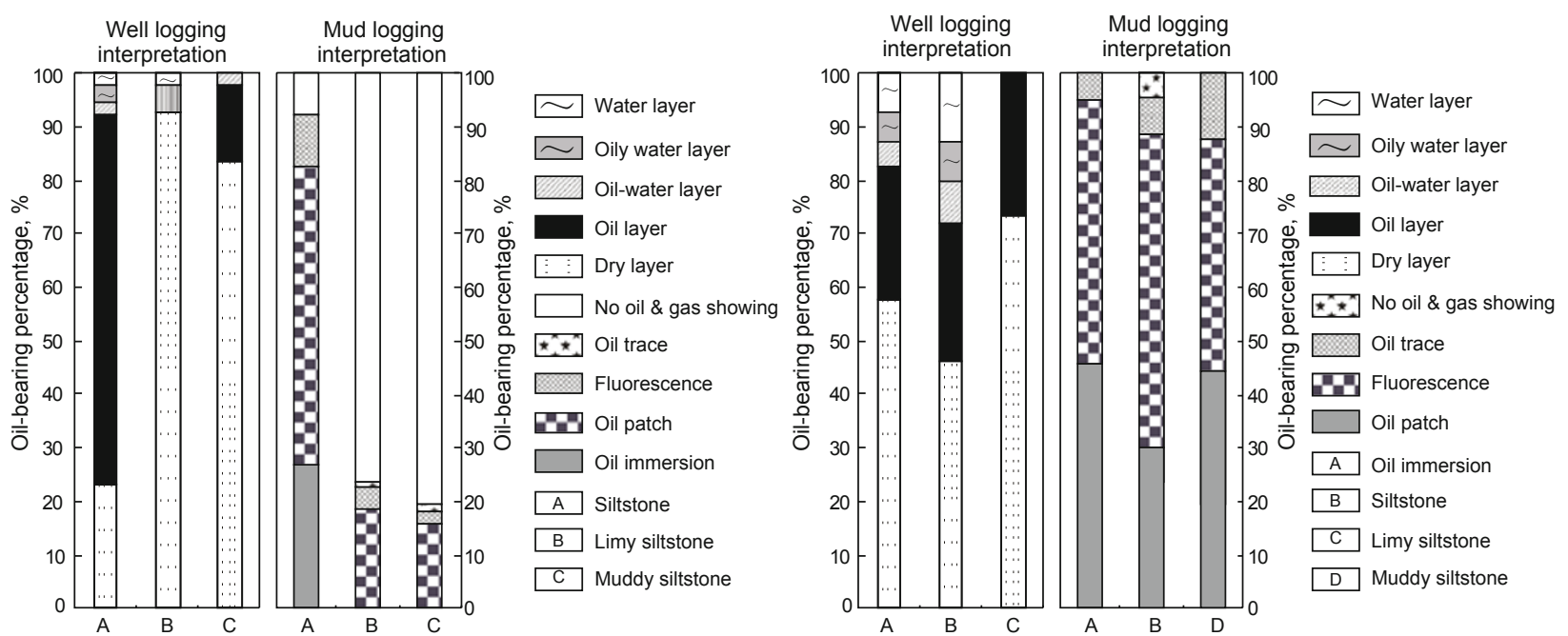

Fig. 5 Histogram of oil-bearing properties of different lithologies. The left one is the Boxing oilfield, and the right one is the Wangjiagang oilfield

Reservoir bed heterogeneity affects migration and controls accumulation and distribution of hydrocarbon as well as oil saturation (Shan et al, 2007), resulting in different hydrocarbon distributions in different well blocks. Taking sandstone group 0 as an example, C95-1 and B6-31 well blocks with excellent structural conditions contain less hydrocarbon than the T85 well block, due to reservoir bed heterogeneity (Fig. 6). The analysis of reservoir bed conditions of sandstone group 0 by choosing representative wells in three well blocks shows that the average sandstone thickness of T85 well block is large, the net-to-gross ratio (the ratio of the thickness of sandstone to the thickness of strata) is higher than the other two, with few interbeds and interlayer heterogeneity. Therefore, the T85 well block with less reservoir bed heterogeneity is more favorable for hydrocarbon accumulation (Table 1).

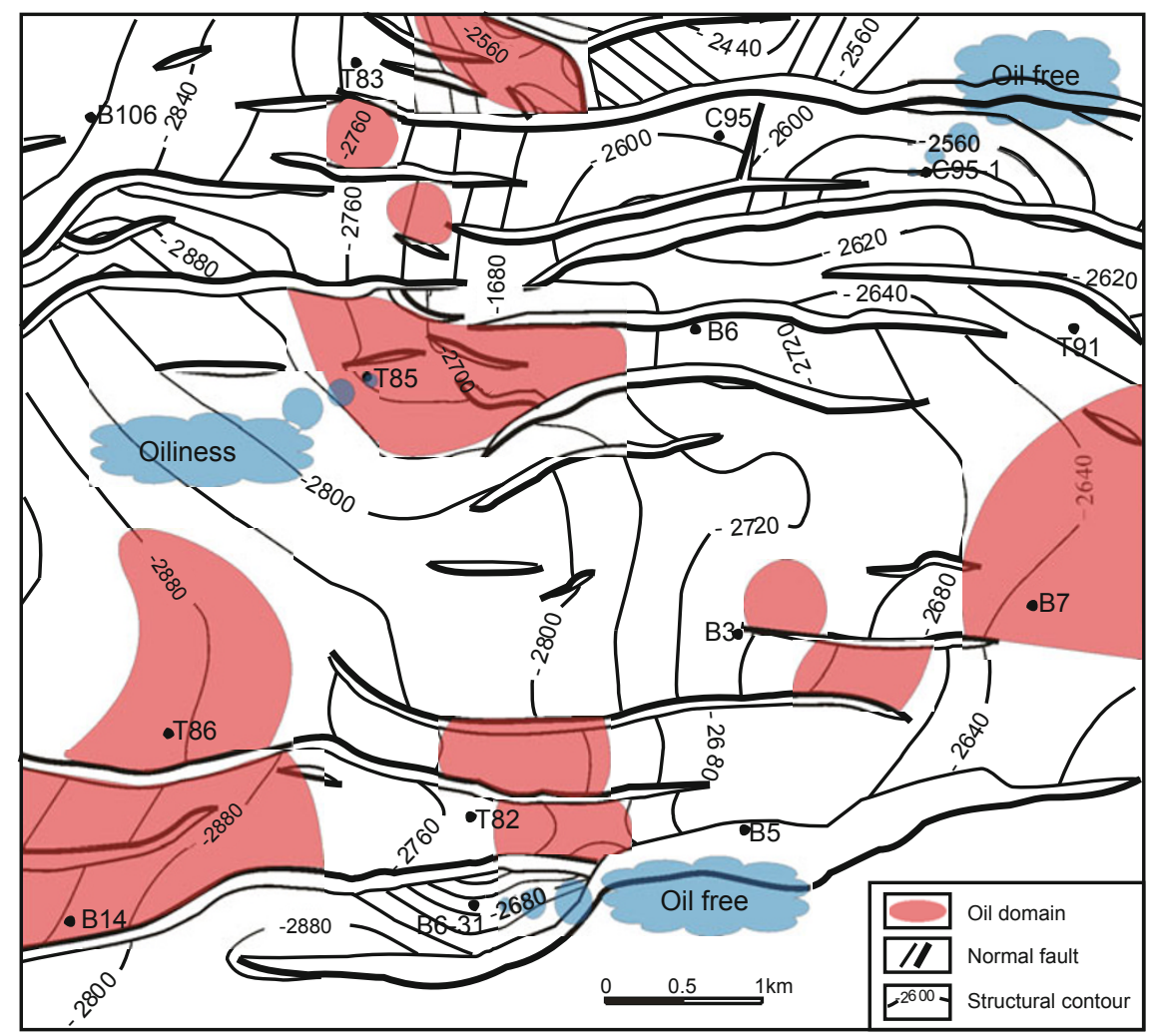

Fig. 6 Planar hydrocarbon distribution in sand group 0, Boxing oilfield 
Table 1 Comparison of reservoir bed properties in different well blocks with similar structural setting, Boxing oilfield

\begin{tabular}{|c|c|c|c|c|c|c|}
\hline Well block & Well name & $\begin{array}{l}\text { Range of sandstone } \\
\text { thickness, } m\end{array}$ & $\begin{array}{l}\text { Average sandstone } \\
\text { thickness, } \mathrm{m}\end{array}$ & $\begin{array}{l}\text { Total sandstone } \\
\text { thickness, m }\end{array}$ & Net-to-gross ratio & Total interbeds \\
\hline \multirow{4}{*}{ C95-1well block } & C95-2 & $0.8-1.2$ & 0.9 & 3.8 & 0.19 & 4 \\
\hline & C95 & $0.8-1.6$ & 1.2 & 4.9 & 0.24 & 4 \\
\hline & C95-1 & $0.8-1.3$ & 1.1 & 4.3 & 0.26 & 4 \\
\hline & C95-X3 & $0.6-1.9$ & 1.2 & 4.9 & 0.27 & 4 \\
\hline \multirow{4}{*}{ T85 well block } & T85 & $0.5-1$ & 0.8 & 1.5 & 0.33 & 2 \\
\hline & $\mathrm{T} 85-1$ & $1.1-1.4$ & 1.25 & 2.5 & 0.4 & 2 \\
\hline & $\mathrm{T} 85-5$ & $1.3-1.7$ & 1.5 & 4.5 & 0.37 & 3 \\
\hline & $\mathrm{T} 85-\mathrm{C} 3$ & $0.9-1.2$ & 1.05 & 2.1 & 0.23 & 2 \\
\hline B6-31 well block & B6-31 & $1.2-1.3$ & 1.25 & 2.5 & 0.21 & 2 \\
\hline
\end{tabular}

2) Index of reservoir bed quality

The index of reservoir bed quality $\left(I_{\mathrm{RQ}}\right)$ is calculated with a mathematical method by considering all the factors influencing heterogeneity and quality of reservoir beds to reflect reservoir bed quality quantitatively, and then to analyze the relationship between reservoir bed quality and hydrocarbon accumulation.

We adopt principal factor analysis (PFA) for a selection of the factors. First of all, multiple variables are selected randomly whose covariance matrix, correlation matrix and eigenvalue are calculated. Secondly, the principle component of parameters and the cumulative probability of primary components are calculated. The parameters whose cumulative probabilities are more than $85 \%$ will generally be selected for the study of reservoir bed quality. We take porosity, permeability, sandstone thickness, interbed frequency, net-togross ratio, sedimentary microfacies and diagenetic facies as parameters.

According to previous studies, the methods for the evaluation of weights of parameters are mainly the analytical hierarchy process (AHP) and the entropy value method (EVM) (Yang et al, 2004). After weighing the advantages and disadvantages of these methods, it is discovered that the AHP is a good subjective evaluation method, and the EVM is a satisfactory objective evaluation method. In this study, a new method named hierarchy-entropy combination assigning method is proposed, which can take full advantages of the two methods. When the sample data is relatively adequate, the weight coefficients from EVM are more reasonable, while the new method will improve the subjectivity of AHP. When the sample data is not adequate, the estimate from the experience of experts will be more important and the new method can improve the inaccuracy of EVM. So, if the quantity of sample data is not known, it is a good choice to use the hierarchyentropy combination assigning method.

The calculation is as follows:

1) The original parameter data matrix $A=\left(a_{i j}\right)_{m \times n}$ is normalized into $b_{i j}$ according to Eqs. (1) and (2), and matrix $B=\left(b_{i j}\right)_{m \times n}$ is generated;

$$
\begin{gathered}
b_{i j}=\frac{a_{i j}-a_{i j \min }}{a_{i j \max }-a_{i j \min }} \\
b_{i j}=\frac{a_{i j \max }-a_{i j}}{a_{i j \max }-a_{i j \min }}
\end{gathered}
$$

Normalize the parameters whose values are relatively large and indicate good reservoir bed quality according to Eq. (1), and normalize the parameters whose values are relatively large and indicate poor reservoir bed quality according to Eq. (2).

What needs to be emphasized is that sedimentary microfacies and diagenetic facies have no values and need to be assigned.

2) Calculate the entropy of the $j$-th parameter according to Eq. (3):

$$
E_{j}=-k \sum_{i=1}^{m}\left(\frac{b_{i j}}{\sum_{i=1}^{m} b_{i j}}\right) \lg \left(\frac{b_{i j}}{\sum_{i=1}^{m} b_{i j}}\right) \quad(j=1,2, \ldots, n)
$$

$$
k=\frac{1}{\ln m}, \text { if } b_{i j}=0 \text {, then }\left(\frac{b_{i j}}{\sum_{i=1}^{m} b_{i j}}\right) \lg \left(\frac{b_{i j}}{\sum_{i=1}^{m} b_{i j}}\right)=0 .
$$

3) Calculate the weight of $j$-th parameter $v_{j}$ as the Eq. (4):

$$
v_{j=} \frac{1-E_{j}}{n-\sum_{j=1}^{n} E_{j}} \quad\left(0 \leq v_{j} \leq 1, \sum_{j=1}^{n} v_{j}=1\right)
$$

4) Calculate the weight coefficients of all parameters $\Phi_{j}$ by means of AHP, and use $\Phi_{j}$ to correct $v_{j}$ as the Eq. (5), and then the new weight coefficients $\lambda_{j}$ are obtained.

$$
\lambda_{j}=\frac{\omega_{j} v_{j}}{\sum_{j=1}^{n} \omega_{j} v_{j}} \quad(j=1,2, \ldots, n)
$$

5) Put the results of normalization of the parameters into Eq. (6), and the index of reservoir bed quality $I_{\mathrm{RQ}}$ is obtained.

$$
I_{\mathrm{RQ}}=\sum_{j=1}^{n} \lambda_{j} b_{i j} \quad(i=1,2, \ldots, m)
$$


The $I_{\mathrm{RQ}}$ stays between 0 and 1. Zero stands for nonreservoir bed, 1 for homogeneous reservoir bed, the higher, the better. According to analysis, the reservoir bed quality of a specific microfacies is similar but it varies from microfacies to microfacies. The main bar-body microfacies is the best, followed by bar-border microfacies and beach mat microfacies. The characteristics and distribution of reservoir bed quality are different because of different sedimentary microfacies of different main beds. Hydrocarbon accumulation is better in regions where reservoir bed quality is high, demonstrating that reservoir heterogeneity is an important factor leading to non-uniform hydrocarbon distribution (Fig. 7). Generally, $I_{\mathrm{RQ}}$ is above 0.4 in the main hydrocarbon region, and the $I_{\mathrm{RQ}}$ in the study area is from 0.25 to 0.65 . Reservoir bed quality in the Wangjiagang oilfield is better than that in the Boxing oilfield.
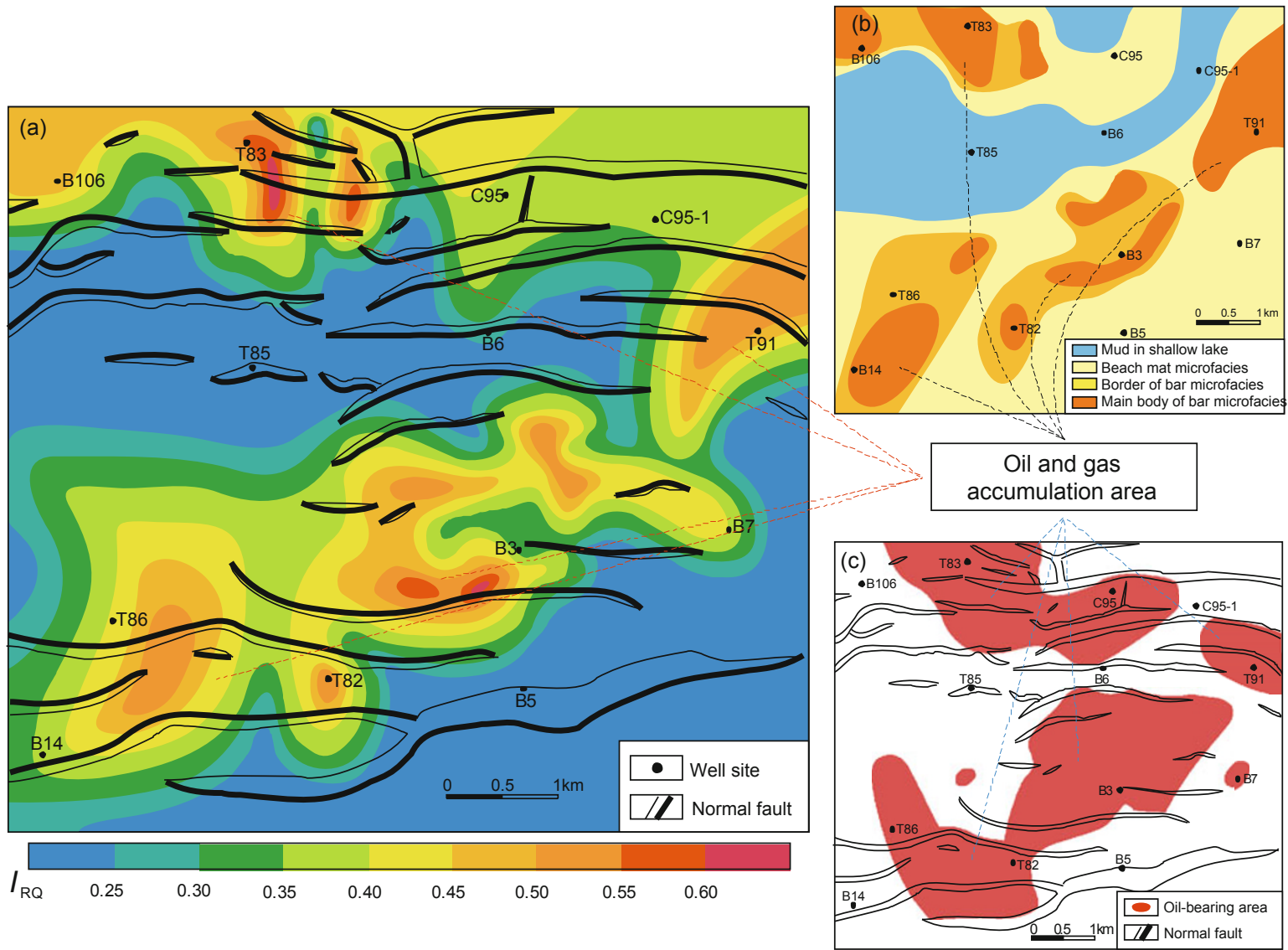

Fig. 7 Comparison of $I_{\mathrm{RQ}}$, sedimentary microfacies and oil area of 3-1 bed, sand group 1, Boxing oilfield.

(a) The plane distribution of $I_{\mathrm{RQ}}$, and color from blue to red indicates reservoir bed quality from bad to good; (b) The plane distribution of sedimentary microfacies, including main bar-body microfacies, bar-border microfacies, beach mat microfacies and shallow-littoral lake mudstones; (c) The plane distribution of oil-bearing area, and the main oil area corresponds to main bar-body and bar-border microfacies where the reservoir bed quality is better.

\subsubsection{Influence of migration conditions on hydrocarbon accumulation}

There are four kinds of migration pathways of oil and gas accumulation in the study area: interconnected pores, microbedding planes and layer interfaces, micro-fractures and faults (Fig. 8). In the Boxing oilfield, the quality of reservoir bed is not good with low permeability and low porosity, and dry zones are common while oil-water interfaces and water zones are rare. The main lateral migration pathways here are microbedding planes and layer interfaces instead of interconnected pores. Due to the presence of thin interbedded sand and mud, the area where total sand thickness is large has more microbedding planes and layer interfaces, so the lateral migration of hydrocarbon is better. Fractures and faults are important pathways of vertical migration of oil and gas, and can affect the layers containing oil and gas. In the Wangjiagang oilfield, because of the fault system, oil and gas are inclined to migrate stepwise through faults or be sealed by faults forming a number of fault-nose reservoirs and fault-block reservoirs. The reservoir bed quality of this area is relatively better and there are a large number of water zones providing more pathways for lateral migration of oil and gas.

Sand body distribution, structural configuration and fault systems control the direction of regional migration and location of hydrocarbon accumulation (Chen et al, 2008; Pang et al, 2008). Under the premise of existing unblocked pathways of oil and gas transportation, structural highs with good reservoir bed quality are favorable locations for oil and gas accumulation. Taking sand group 1 in the Boxing oilfield 

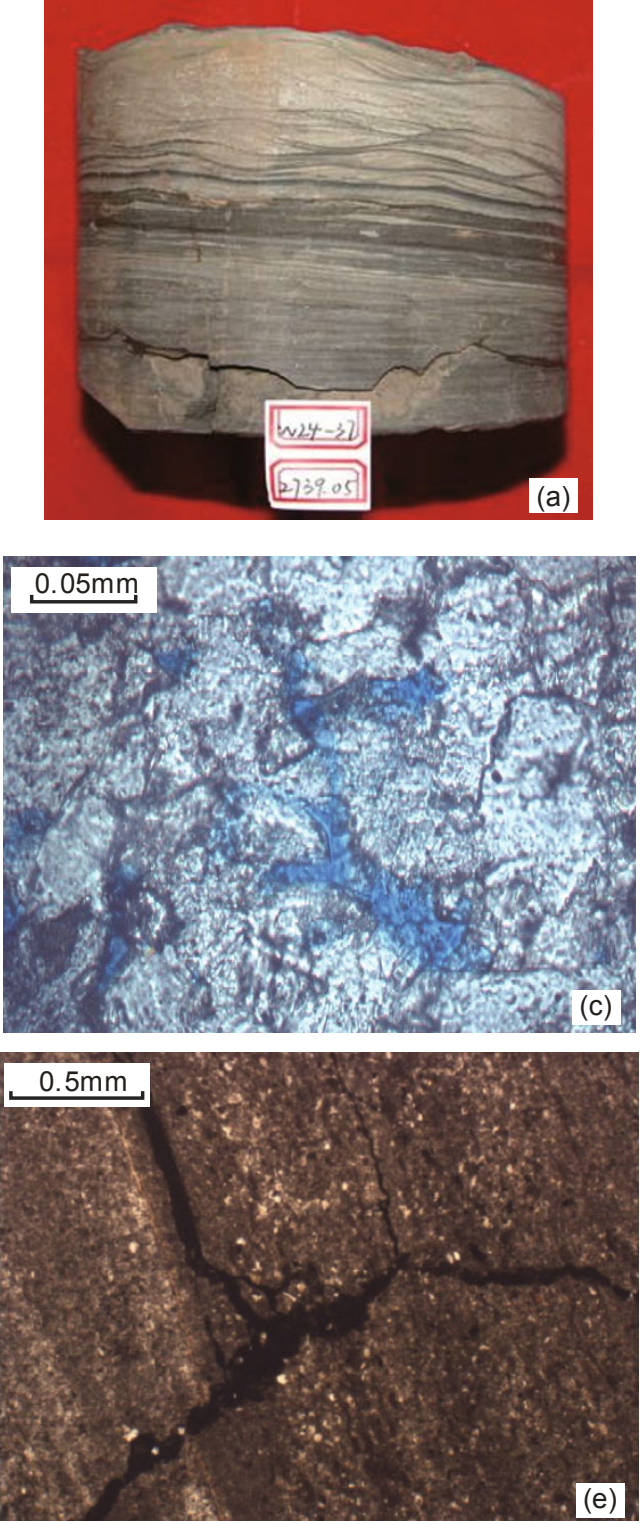
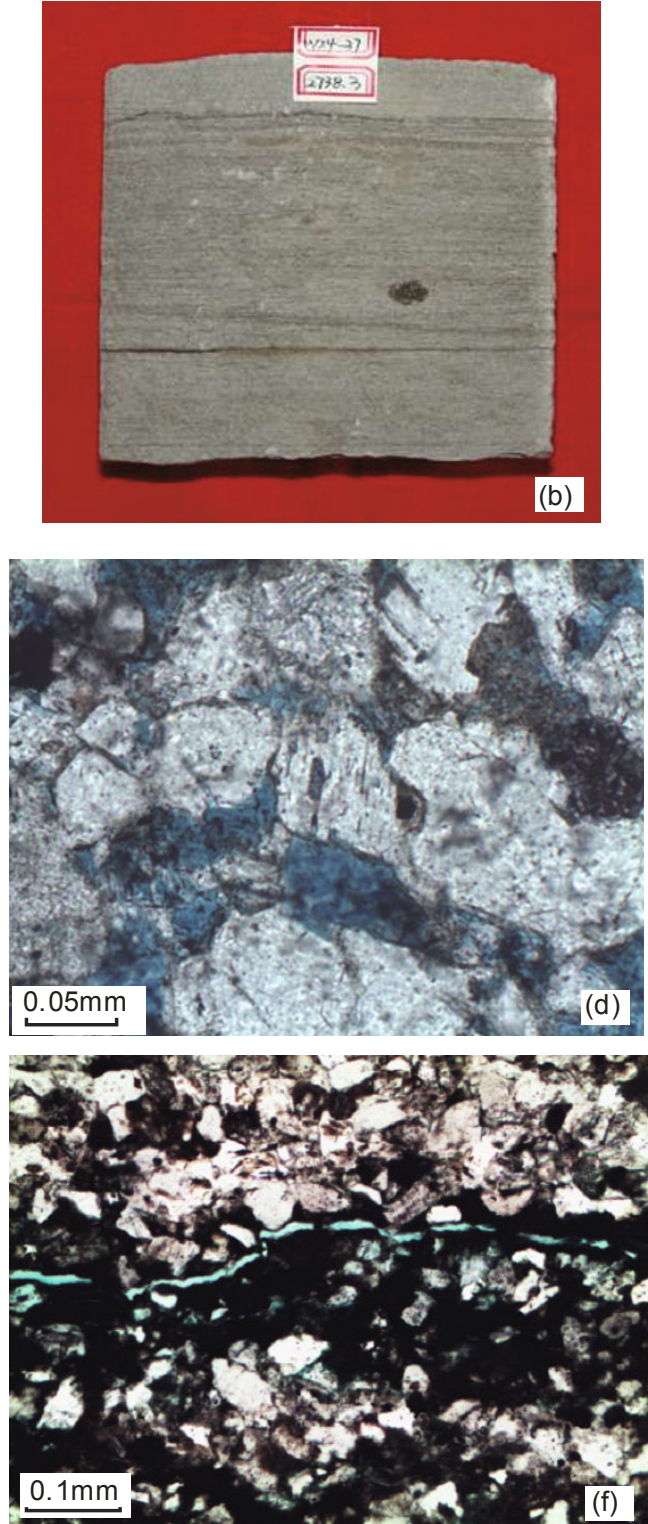

Fig. 8 Main types of hydrocarbon migration pathways.

(a) Wavy beddings, W24-37 Well, 2739.05 m; (b) Parallel beddings, W24-37 Well, $2738.3 \mathrm{~m}$; (c) Intergranular secondary pores, T83-9 Well, $2766.12 \mathrm{~m}$, blue casting thin section, single polarized light, $\times 320$; (d) Intragranular dissolution pores, T83-9 Well, $2672 \mathrm{~m}$, blue casting thin section, single polarized light, $\times 200$; (e) Tectonic fractures, W21-3 Well, $2552.5 \mathrm{~m}$, single polarized light, $\times 40$; (f) Fractures filled by asphalt, W125 Well, $2786.4 \mathrm{~m}$, single polarized light, $\times 100$

as an example, the B3 well block in the central area has good sand bodies and ideal tectonic background which is beneficial for the accumulation of oil and gas and contributes to the formation of reservoirs mainly controlled by tectonic factors (fault reservoirs, fault-lithologic reservoirs); the T83 well block in the northern part is located in the structural high with moderate-to-good reservoir bed and is a relatively favorable area for hydrocarbon accumulation. The reservoirs there are mainly fault-lithologic reservoirs (Fig. 9).

\subsubsection{Discussion}

In order to study the relationship between reservoir bed physical properties and hydrocarbon-bearing properties, the data on porosity and oil saturation in the Boxing oilfield were analyzed. The results showed that the reservoir bed quality obviously influenced hydrocarbon-bearing properties in a specific range. When the porosity was less than $14 \%$, oil saturation had a very significant positive correlation with porosity, reflecting that the increasing amount of oil and gas was related to the reduction of resistance of hydrocarbon accumulation. When the porosity was more than $14 \%$, the positive correlation was not obvious (Fig. 10). It indicated that the reservoir condition was not the key controlling factor of hydrocarbon accumulation when reservoir bed physical properties reached a specific level, and other factors, such as tectonic background and oil source would play a more important role. The average porosity was $12.8 \%$ in the beachbar sandstone reservoirs of $\mathrm{Es}_{4}{ }^{\mathrm{s}}$ in the Boxing oilfield, and it was $15.9 \%$ in the Wangjiagang oilfield, suggesting that the control functions of reservoir bed conditions for hydrocarbon accumulation in two oilfields were different. 


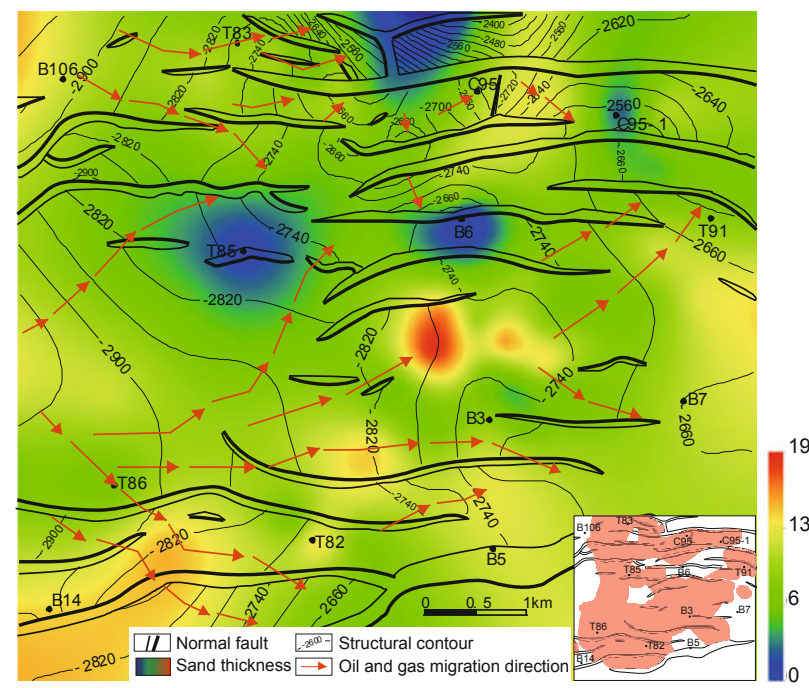

Fig. 9 Configuration map of hydrocarbon migration factors in sand group 1, Boxing oilfield. The background color is the thickness of sand body, and color from blue to red indicates increasing sand thickness; the arrows indicate hydrocarbon transporting direction; the contour lines are the structural contour of sand group 1

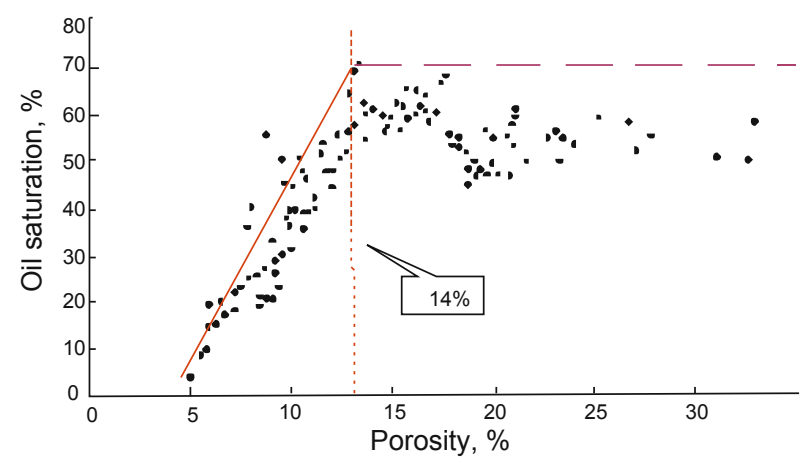

Fig. 10 Comparison of porosity and oil saturation in the Boxing oilfield

\subsection{Mechanism of hydrocarbon accumulation}

\subsubsection{Driving force and resistance of hydrocarbon accumulation}

According to prior studies (Zou, 2008), for beach-bar sandstones, when the formation pressure coefficient is above 1.3 , abnormal high pressure is the main driving force for hydrocarbon accumulation; when the formation pressure coefficient is less than 1.2, buoyancy is the main driving force for hydrocarbon accumulation; when the formation pressure coefficient is 1.2-1.3, both abnormal high pressure and buoyancy are important. Fault systems are the main pathway for oil and gas migration in any circumstances.

The relationship between driving force and resistance is another key factor for hydrocarbon accumulation ( $\mathrm{Li}$ et al, 2004; Sui et al, 2008; Zhang et al, 2009). The difference of driving force and resistance controls differential distribution of oil and gas. In the Boxing oilfield, the driving forces of hydrocarbon migration are different in different well blocks and sand groups, but the resistance is approximately the same. The T83-C95 well block has the highest driving force and the B3 well block is the next. For different sand groups, sand group 0 , sand group 2 and sand group 4 have a lower driving force which is not favorable for hydrocarbon accumulation; sand group 3 and sand group 5 have a higher driving force but less sandstones, which are also unfavorable for hydrocarbon accumulation. Comprehensive analysis shows that sand group 1 is the most favorable, which is also consistent with actual distribution of hydrocarbon (Fig. 11).
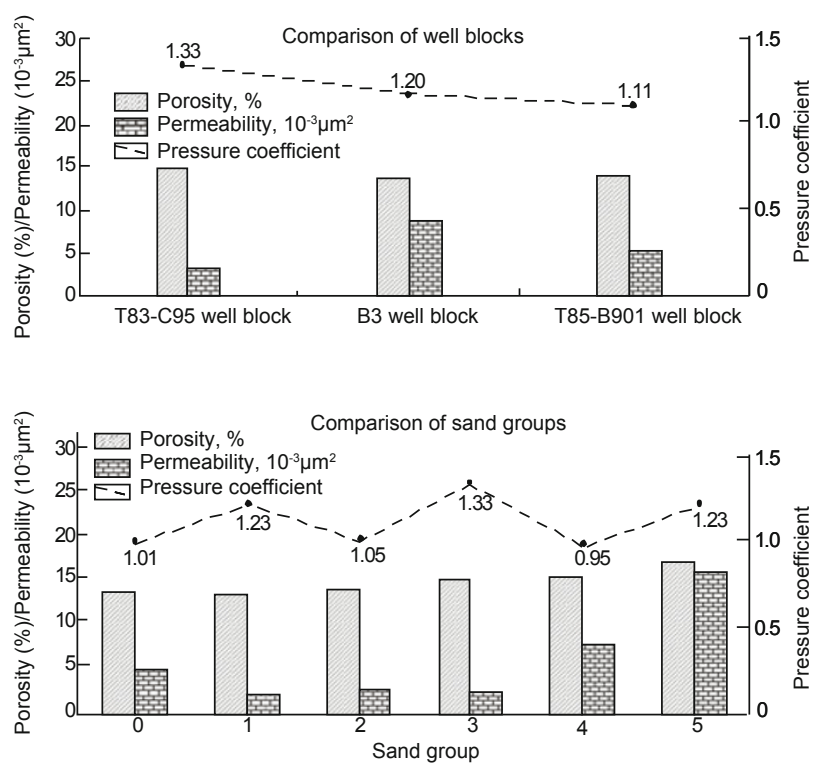

Fig. 11 Comparison of driving force and resistance for hydrocarbon accumulation in $\mathrm{Es}_{4}{ }^{\mathrm{s}}$, Boxing oilfield. Formation pressure coefficient means driving force, and porosity and permeability mean resistance, as well as the relationship of driving force and resistance reflects the characteristics of hydrocarbon accumulation

\subsubsection{Model experiment}

The mechanism of hydrocarbon migration and accumulation in reservoirs and traps is one of the key problems in petroleum geology and also the weak point in the research on hydrocarbon accumulation (Tokunaga et al, 2000; Shi et al, 2010). Our study on the mechanism of hydrocarbon accumulation in beach-bar sandstones analyzed the characteristics of hydrocarbon migration and accumulation with an experimental model (Rezaei and Chatzis, 2011). According to the change of migration driving force and the relationship of faults and heterogeneous sandstones, the selective accumulation mechanism and distribution of hydrocarbon in the process that hydrocarbon migrated along the fault vertically were discussed.

As illustrated in Fig. 12, the sand body with mixed grain size in the middle of the geological model in the experiment simulates a fault breccia zone, as the main path for vertical migration. The grain size grades of different sand layers are different, as shown in Table 2. Kerosene with a density of 0.75 $\mathrm{g} / \mathrm{cm}^{3}$ with a little red dye was injected by constant-flux pump for observation, simulating the hydrocarbon expulsion from source rock, and brine of $15 \mathrm{~g} / \mathrm{L}$ salinity was used to simulate formation water. 


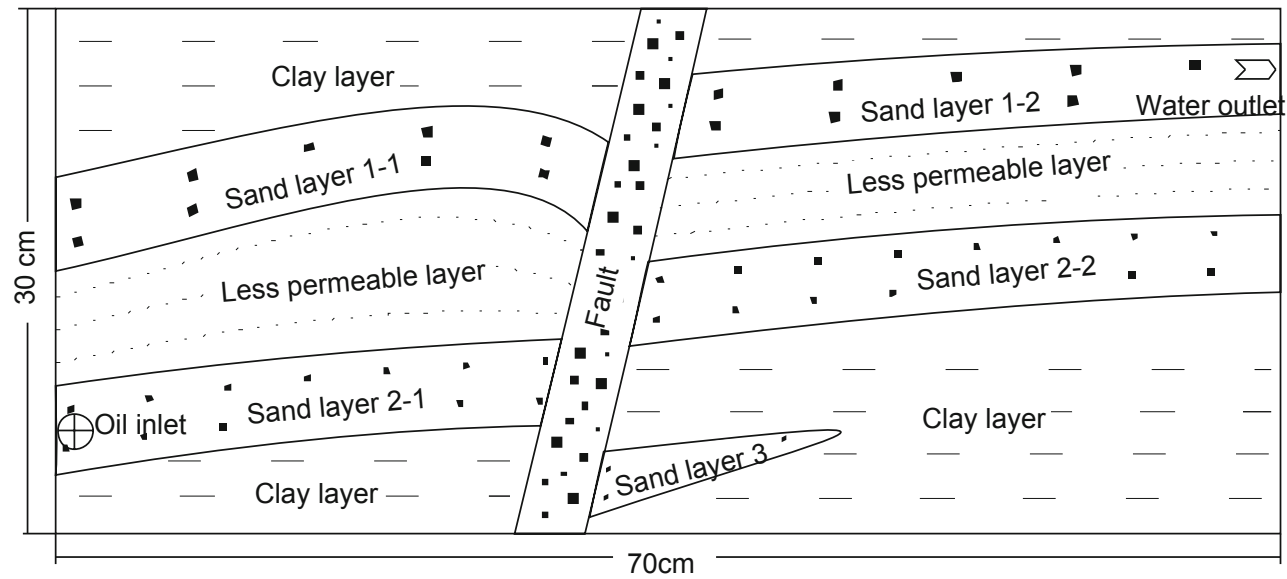

Fig. 12 Sketch map of experimental model

Table 2 Physical properties parameters of different sand layers

\begin{tabular}{cccc}
\hline Position & Particle size, $\mathrm{mm}$ & Porosity, $\%$ & Permeability, $10^{-3} \mathrm{\mu m}^{2}$ \\
\hline Sand layer 1-1 & $0.20-0.25$ & 36 & 3750 \\
Sand layer 1-2 & $0.20-0.25$ & 36 & 3750 \\
Sand layer 2-1 & $0.15-0.20$ & 35 & 2150 \\
Sand layer 2-2 & $0.15-0.20$ & 35 & 2150 \\
Sand layer 3 & $0.10-0.15$ & 33 & 1642 \\
Fault & $0.05-0.20$ & 30 & 1156 \\
Less permeable layer & $0.05-0.08$ & 28 & 426 \\
\hline
\end{tabular}

In the experiment, the initial flow rate of the constantflux pump was set at $0.5 \mathrm{~mL} / \mathrm{min}$. When $60 \mathrm{~mL}$ of kerosene was injected, kerosene diffused around the oil inlet and then migrated along sand layer 2-1 updip (Fig. 13(a)).

When the injection reached $300 \mathrm{~mL}$, kerosene entered the fault and migrated updip along sand layer 2-2. At this moment, kerosene was concentrated in the upper and middle of sand layer 2-1, and the path of migration from left to right was narrower (Fig. 13(b)).

When $720 \mathrm{~mL}$ of kerosene had been injected, there was more and more kerosene in sand layer 2-2, and was seen everywhere apart from the right hand side. Some kerosene continued to migrate along the fault to sand layer 1-1. Importantly, in this case, no kerosene was present in the fault downdip, with sand layer 3 as a water bed (Fig. 13(c)).

When the flow rate was adjusted to $2 \mathrm{~mL} / \mathrm{min}$ and injection reached $1,320 \mathrm{~mL}$, kerosene migrated to the anticline trap of sand layer 1-1, appearing in the lower part of the spill point of the trap. Kerosene could be seen on the top part of fault and sand layer 1-2 with lighter color and lower oil saturation. The obvious change was that kerosene filled the fault downdip, migrating to sand layer 3, making it an oilwater bed (Fig. 13(d)).

When the flow rate was adjusted to $4 \mathrm{~mL} / \mathrm{min}$ and injection reached 2,040 mL, sand layer 3 was full of kerosene. The kerosene amount in the trap in sand layer 1-1 increased, as seen beneath the oil-water interface, because of higher flow rate. The color of kerosene in sand layer 1-2 became darker, while kerosene was seen in water outlet (Fig. 13(e)).

When the flow rate was adjusted to $0.5 \mathrm{~mL} / \mathrm{min}$ and injection reached $2,350 \mathrm{~mL}$, the color of the sand layers full of kerosene was dark, the kerosene amount beneath the oilwater interface in sand layer 1-1 decreased, with light oil fleck, demonstrating that kerosene migrated updip along the fault under buoyancy. At this moment, inflow and outflow reached balance, the migration and accumulation of kerosene in the model was stabilized. The injection process came to an end (Fig. 13(f)).

At the end of the experiment, the oil saturation of the anticline trap and updip pinchout sand layer was larger, so was the region nearer the oil inlet. In the area far away from the oil inlet, the kerosene amount in the right side of sand layer 1-2 was smaller. The saturation in the fault which was the vertical migrating path was larger. And in the case of faster injection, kerosene would be contained in the fault downdip.

According to the experiment, firstly, the heterogeneity of reservoir beds played a significant role in hydrocarbon distribution and oil saturation. The difference of permeability among the beds led to the differences of oil filling, with no oil in beds of low permeability. Secondly, the rate of injection also played an important role in hydrocarbon distribution in sand body as well as migration of hydrocarbon. Due to better quality of sand layer 2-1 than that of faults, migration of hydrocarbon from the sand layer to fault should overcome the difference in displacement pressure. At the regular flow rate, when the oil column had accumulated to some extent, the fault could not seal, and became a migration path. However, if the flow rate was increased, offering more push to overcome the resistance from difference in displacement pressure and buoyancy, oil would migrate along the fault downdip leading to back-fill into sand layer 3. Notably, even if the flow rate was up to $4 \mathrm{~mL} / \mathrm{min}$, kerosene still could not be filled into the less permeable layers which played the role of barrier. There was a threshold value of sand body quality. When it was lower than the threshold value, the sand body was not effective for hydrocarbon accumulation. Thirdly, buoyancy played an important role in hydrocarbon migration. When the flow rate was low, buoyancy was the main driving force, with the help of which, kerosene would migrate updip to higher permeability and smaller resistance. When the flow rate was increased, the driving force of migration was also increased, filling kerosene into the lower permeability sand beds. 

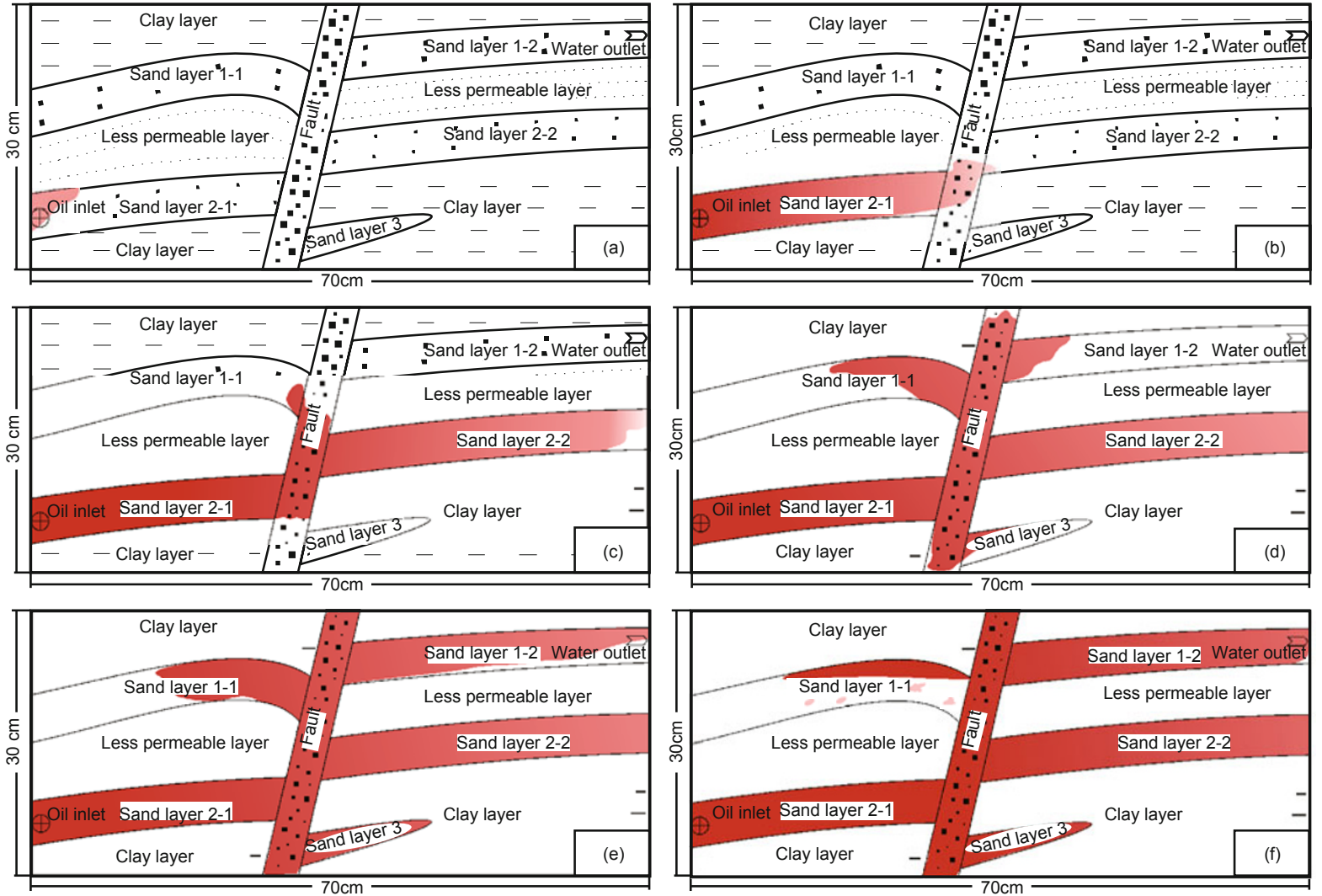

Fig. 13 Sketch map of hydrocarbon migration

\subsubsection{Discussion}

According to our study, although beach-bar sandstones were developed in $\mathrm{Es}_{4}{ }^{\mathrm{s}}$ in both the Boxing and Wangjiagang oilfields, the difference in hydrocarbon accumulation was significant. Influenced by provenance and diagenesis in the Boxing oilfield because of poor quality and strong heterogeneity, reservoir beds with hydrocarbon updip and dry bed downdip alternated with reservoir beds with hydrocarbon updip and water downdip, the reservoir bed border with unequal altitude was mainly controlled by reservoir bed quality. Oil and gas mainly accumulated in the "sweet spots" with good reservoir bed quality, forming capillary sealing reservoirs and fault-lithologic reservoirs. Therefore, there was a better correspondence between hydrocarbon distribution and reservoir bed quality, demonstrating that reservoir bed conditions played the most significant role in hydrocarbon accumulation. In the Wangjiagang oilfield, the reservoir bed quality was better, and many sandstone layers were cut by faults. If the faults sealing properties were poor, faults would be the pathways of migration, if not, faults would provide sealing for accumulation. Therefore, the reservoir types in this area are mainly fault-block, fault-nose and fault-lithologic reservoirs. The analysis of sealing properties of faults is of great significance for guiding petroleum exploration in the study area, and exploration targets should be structural reservoirs developed in structural highs with good reservoir bed quality.

Based on the analysis of characteristics and diversity of hydrocarbon accumulation in both the Boxing and Wangiiagang oilfields, two hydrocarbon accumulation models are proposed. One is the hydrocarbon accumulation model controlled by reservoir bed heterogeneity and the second is the hydrocarbon accumulation model controlled by the complex migration system with faults connecting sandbodies (Fig. 14).
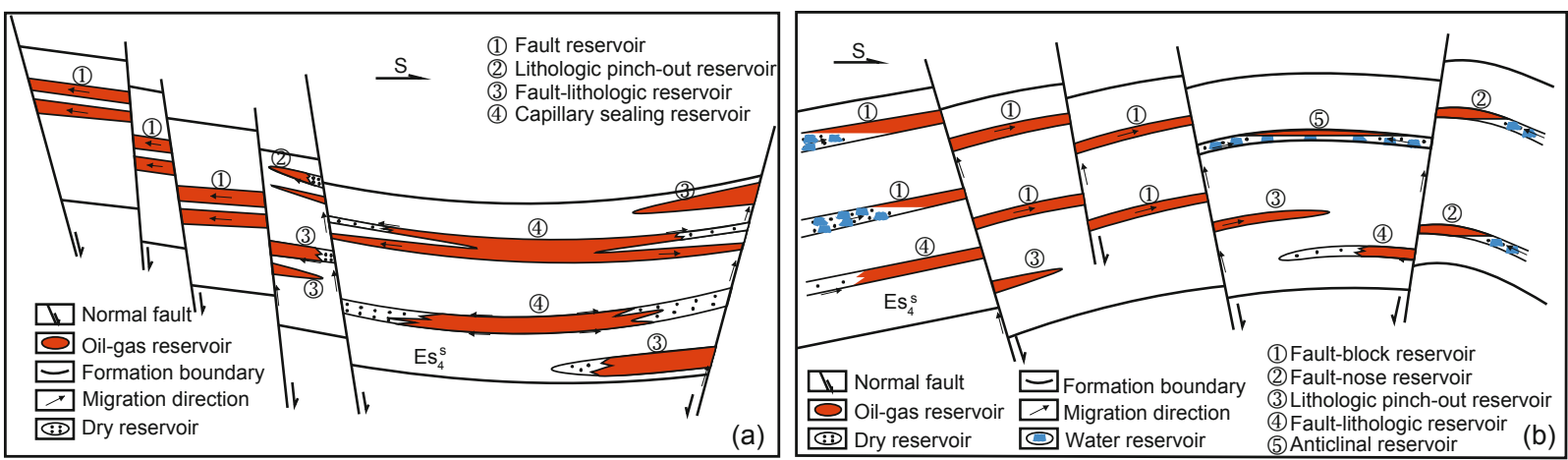

Fig. 14 Sketch map of the hydrocarbon accumulation models

(a) Hydrocarbon accumulation model controlled by reservoir bed heterogeneity, Boxing oilfield; (b) Hydrocarbon accumulation model controlled by the complex migration system with faults connecting sandbodies, Wangjiagang oilfield 


\section{Conclusions}

1) Hydrocarbon distribution in beach-bar sandstones is non-uniform in the study area. The reservoirs in the Boxing oilfield are mainly capillary sealing and fault-lithologic reservoirs, whereas in the Wangjiagang oilfield there are fault-block and fault-nose reservoirs.

2) Reservoir bed condition is the main controlling factor of hydrocarbon accumulation in the Boxing oilfield. The reservoir bed quality there is poor and has a good correspondence with hydrocarbon-bearing properties. Hydrocarbon distribution is controlled by reservoir bed heterogeneity. The faults in the Wangjiagang oilfield weaken the control of hydrocarbon distribution by reservoir bed condition to a specific extent.

3) Migration pathways are the important condition of hydrocarbon accumulation in the Wangjiagang oilfield. Plenty of faults and sandstone layers with good quality provide stepwise or reticulate migration systems for oil and gas. At the same time, faults can provide sealing for hydrocarbon accumulation. Numerous fault-block reservoirs and faultnose reservoirs directly prove the importance of faults in hydrocarbon accumulation in the area.

4) The relationship between driving force and resistance is another key controlling factor for hydrocarbon accumulation. According to our experiment, a change of driving force would lead to selective in-filling of hydrocarbon to heterogeneous sandbodies, giving better reservoir beds more hydrocarbon, thus impacting on hydrocarbon accumulation and distribution.

5) Based on the analysis of play elements in both the Boxing and Wangjiagang oilfields, two hydrocarbon accumulation models are proposed. One is a hydrocarbon accumulation model controlled by reservoir bed heterogeneity and the second is a hydrocarbon accumulation model controlled by a complex migration system with faults connecting sandbodies. Different exploration strategies should be adopted for the detailed exploration of beach-bar sandstone reservoirs according to different geological backgrounds. For the reservoir beds with poor quality and strong heterogeneity, the reservoir bed quality should be evaluated first, and then the "sweet spots" should be the primary targets. For the regions that suffered strong tectonic movements, hydrocarbon migration pathways (faults and unconformities) should be analyzed to determine the favorable direction of oil and gas migration, and structural reservoirs developed in structural highs with good reservoir bed quality should be the primary targets.

\section{Acknowledgements}

This study was financially supported by National Major Projects of Fine Characterization of Complex Hydrocarbon Reservoir and Prediction of Remaining Oil Distribution (No. 20095009-003). The authors are grateful to Li Ru and Li Xiaoqing from Shengli Oil Field Company, SINOPEC for their help and supply of analysis and testing data for this study.

\section{References}

Borer J M. High-resolution stratigraphy of the Green River Formation at Raven Ridge and Red Wash Field, NE Uinta Basin: Facies and stratigraphic pattern in a high-gradient high-energy lacustrine system. Salt Lake City: AAPG Annual Convention-Field Trip \#4. 2003

Cao Y C, Wang J and Liu H M. Preliminary study on the hydrodynamic mechanism of beach-bar sandbodies with environmentally sensitive grain size components: A case study from beach-bar sandbody sediments of the upper part of the fourth member of the Shahejie Formation in the western Dongying Sag. Acta Sedimentologica Sinica. 2010. 28(2): 274-283 (in Chinese)

Castelle B, Bonneton P, Dupuis H, et al. Double bar beach dynamics on the high-energy meso-macrotidal French Aquitanian Coast: a review. Marine Geology. 2007. 245: 141-159

Chen D X, Pang X Q, Zhang S W, et al. Control of facies/potential on hydrocarbon accumulation: a geological model for lacustrine rift basins. Petroleum Science. 2008. 5(3): 212-222

Deng H W, Gao X P, Zhao N, et al. Genetic types, distribution patterns and hydrocarbon accumulation in terrigenous beach and bar in northern faulted-lacustrine-basin of Jiyang Depression. Journal of Palaeogeography. 2010. 12(6): 737-747 (in Chinese)

Frey R W and Howard J D. Beaches and beach-related facies, Holocene barrier islands of Georgia. Geological Magazine. 1988. 125: 621-640

Guzmán J I and Fisher W L. Early and middle Miocene depositional history of the Maracaibo Basin, western Venezuela. AAPG Bulletin. 2006. 90: 625-655

Han H W. Research on the characteristics of thin-alternating-bed seismic waveform-A case study of the beach bar sandstones of $\mathrm{Es}_{4}$ in Boxing Sub-sag. Earth Science Frontiers. 2009. 16(3): 349-355 (in Chinese)

Houser C and Greenwood B. Profile response of a lacustrine multiple barred nearshore to a sequence of storm events. Geomorphology. 2005. 69: 118-137

Jiang Z X, Liu H, Zhang S W, et al. Sedimentary characteristics of largescale lacustrine beach-bars and their formation in the Eocene Boxing Sag of Bohai Bay Basin, East China. Sedimentology. 2011. 58(5): 1087-1112

Li G B, Jiang Z X, Chen S W, et al. Sedimentary characteristics and controlling factors of beach bars in the upper submember of the fourth member of the Shahejie Formation in the Lijin Sub-sag. Geology in China. 2008a. 35(5): 911-921 (in Chinese)

Li G F, Cao M Q and Zhou H. Effects of near-surface absorption on reflection characteristics of continental interbedded strata: the Dagang oilfield as an example. Acta Geologica Sinica (English Edition). 2010. 84(5): 1306-1314

Li P L. Oil/gas distribution patterns in Dongying Sag, Bohai Bay Basin. Journal of Petroleum Science and Engineering. 2004. 41: 57-66

Li P L, Pang X Q, Chen D X, et al. Formation mechanism and model for sand lens reservoirs in the Jiyang Depression, East China. Science in China Series D: Earth Sciences. 2004. 47(suppl.): 167-176

Li S M, Jiang Z X, Liu K Y, et al. Origin of oils in "subtle pools" in the Dongying Sag, Bohai Bay Basin, China. Acta Geologica Sinica (English Edition). 2008b. 82(1): 184-196

Li S M, Qiu G Q, Gao Y J, et al. Formation and accumulation of hydrocarbons in the central uplift, Dongying Sag. Petroleum Science. 2006. 3(3): 12-22

Osborne P D and Greenwood B. Frequency dependent crossshore suspended sediment transport: 1. A nonbarred shoreface. Marine Geology. 1992a. 106: 1-24

Osborne P D and Greenwood B. Frequency dependent crossshore suspended sediment transport: 2. A barred shoreface. Marine Geology. 1992b. 106: 25-51

Otvos E G. Beach ridges definitions and significance. Geomorphology. 2000. 32: 83-108

Pang X Q, Chen D X, Zhang S W, et al. Hydrocarbon accumulation in 
network and its application in the continental rift basin. Science in China Series D: Earth Sciences. 2008. 51(suppl.): 88-100

Reid I and Frostick L E. Beach orientation, bar morphology and the concentration of metalliferous placer deposits: a case study, Lake Turkana, N Kenya. Journal of the Geological Society. 1985. 142: 837-848

Rezaei N and Chatzis I. Characterization of heterogeneities in porous media using constant rate air injection porosimetry. Journal of Petroleum Science and Engineering. 2011. 79: 113-124

Shan X L, Hu J X, Reinhard F S, et al. Sedimentary micro-facies and macro heterogeneity of reservoir beds in the third member of the Qingshankou Formation, Qian'an area, Songliao Basin. Acta Geologica Sinica (English Edition). 2007. 81(6): 1033-1040

Shi G R, Zhang Q C, Yang X S, et al. Oil and gas assessment of the Kuqa Depression of Tarim Basin in western China by simple fluid flow models of primary and secondary migrations of hydrocarbons. Journal of Petroleum Science and Engineering. 2010. 75: 77-90

Si X Q, Zhang J L and Yang Z C. Relation between beach bar sandstone diagenesis and reservoir quality in the upper $\mathrm{Es}_{4}$ of the Palaeogene in the Boxing Sub-sag. Journal of China University of Petroleum (Edition of Natural Science). 2008. 32(2): 6-11 (in Chinese)

Song M S. Diagenesis of member 4 of the Shahejie Formation in the south slope of the Dongying Sag, China. Journal of Chengdu University of Technology (Science \& Technology Edition). 2005. 32(3): 239-245 (in Chinese)

Soreghan M J and Cohen A S. Textural and compositional variability across littoral segments of Lake Tanganyika: The effect of asymmetric basin structure on sedimentation in large rift lakes. AAPG Bulletin. 1996. 80: 382-409

Sui F G, Hao X F, Liu Q, et al. Formation dynamics and quantitative prediction of hydrocarbons of the superpressure system in the Dongying Sag. Acta Geologica Sinica (English Edition). 2008. 82(1): 164-173

Tan L J and Guo S. Hydrocarbon accumulation features and main controlling factors of beach bar sandstone in the upper $\mathrm{Es}_{4}$ formation in the Boxing oilfield, Dongying Sag. Journal of China University of Petroleum (Edition of Natural Science). 2011. 35(2): 25-31 (in Chinese)

Tan L J, Jiang Y L, Su C Y, et al. The characters of source rock and oil source in the Boxing Oilfield, Dongying Sag. Journal of China University of Petroleum (Edition of Natural Science). 2002. 26(5): 1-5 (in Chinese)

Tian J J and Jiang Z X. Sequence stratigraphy characteristics and sedimentary system evolution of the upper $\mathrm{Es}_{4}$ in the Dongying Sag. Acta Geologica Sinica. 2009. 83(6): 836-846 (in Chinese)
Tokunaga T, Mogi K, Matsubara O, et al. Buoyancy and interfacial force effects on two-phase displacement patterns: An experimental study. AAPG Bulletin. 2000. 84: 65-74

Wang G M, Gao L, Lin X M, et al. High frequency cycles and their control of lacustrine shoal-bars in the 4th member of the Shahejie Formation in the southern slope of the Dongying Sag. Journal of Earth Sciences and Environment. 2008. 30(1): 44-48 (in Chinese)

Wang H A, Zhong J H, Yang S Y, et al. Lower oil sand hill formation beach-bar sandstone characteristics and reservoir evaluation in the Wunan-Lucaotan area, Qaidam Basin. Oil Geophysical Prospecting. 2009. 44(5): 597-602 (in Chinese)

Yang S C, Yang Z L and $\mathrm{Hu} \mathrm{H} \mathrm{B.} \mathrm{An} \mathrm{algorithm} \mathrm{of} \mathrm{heterogeneous}$ synthetic index with entropy weight. Journal of China University of Petroleum (Edition of Natural Science). 2004. 28(1): 18-21 (in Chinese)

Yang Y F, Han Y J, Zhong J H, et al. Oil and gas depositional characteristic and distribution law of the Gaotaizi reservoir in the western placanticline, Songliao Basin. Acta Geologica Sinica. 2011a. 85(8): 1377-1388 (in Chinese)

Yang Y Q, Qiu L W, Jiang Z X, et al. A depositional pattern of beach bar in continental rift lake basins: A case study on the upper part of the fourth member of the Shahejie Formation in the Dongying Sag. Acta Petrolei Sinica. 2011b. 32(3): 417-423 (in Chinese)

Yang Z C and Zhang J L. Biomarkers of crude oils and oil-source correlation in the South Slope of the Dongying Sag. Periodical of the Ocean University of China. 2008. 38(3): 453-460 (in Chinese)

Zhang J L and Wang B Q. Beach and bar deposits of the Palaeogene Dongying Formation in the Hejian Oilfield. Scientia Geologica Sinica. 1995. 4(4): 497-504

Zhang S W, Zhang L Y, Zhang S C, et al. Formation of abnormal high pressure and its application in the study of oil-bearing properties of lithologic hydrocarbon reservoirs in the Dongying Sag. Chinese Science Bulletin. 2009. 54(23): 4468-4478

Zhu G Y, Jin Q, Zhang S C, et al. Distribution characteristics of effective source rocks and their control on hydrocarbon accumulation: a case study from the Dongying Sag, Eastern China. Acta Geologica Sinica (English Edition). 2004. 78(6): 1275-1288

Zhu X M, Xin Q L and Zhang J R. Sedimentary characteristics and models of the beach-bar reservoirs in faulted down lacustrine basins. Acta Sedimentologica Sinica. 1994. 12(2): 20-27 (in Chinese)

Zou L. Reservoir distribution and main factors influencing hydrocarbon accumulation of beach-bar sandstone in the Sha4 of Shahejie Formation, gentle slope belt, Dongying Sag. Petroleum Geology and Recovery Efficiency. 2008. 15(2): 34-36 (in Chinese)

(Edited by Hao Jie) 